\title{
Abortion: ensuring access
}

A ccess to reproductive health care is essential to women's health, and for some women, abortion is a key component of that care. But not all women in Canada have adequate, or in some cases any, access to abortion. ${ }^{1}$ It is important for Canadian physicians to know the facts about access to abortion so that they can better protect and promote the health of their female patients.

Many of us assume that, in contrast to the United States, women's access to abortion in Canada is enshrined in law and guaranteed by our health care system. This is not always true. A brief review of history is needed here.

In the rg6os, Canadian physicians and the Canadian women's movement fought against the prohibition of abortion in the Criminal Code. They were successful, and Parliament modified the law to allow abortions where approved by a therapeutic abortion committee. In I988, in Morgentaler, the Supreme Court of Canada recognized that a woman's right to continue or to terminate a pregnancy is protected by the Canadian Charter of Rights and Freedoms and struck down the law. These successes meant that there were no longer restrictions on abortion and that it was regulated like any other medical procedure.

Since the victories in the ig6os and ig8os, however, there has been only limited improvement in access and for only some women. ${ }^{2,3}$ For many teenaged girls and women, particularly those who are poor, live in rural areas, are young, disabled, Aboriginal, are in a racial minority, are immigrants, or who do not speak English or French - those who are the most vulnerable - access to abortion is limited. In some provinces, abortions are not available at all. Only $17.8 \%$ of all general hospitals provide abortion services, ${ }^{3}$ a decrease from 20.I\% in $1977 .{ }^{4}$ Some hospitals require physician referrals, have waiting periods of up to 6 weeks, impose gestational limits or allow abortions only as a "last resort." Clinic abortions are not available in all provinces, and even where available, some clinic abortions cost women \$500-\$750. Some physicians refuse to provide abortion services and refuse to provide women with the information or referrals needed to find help elsewhere. Many women cannot get information about how to access abortion services, and some receive unsolicited anti-abortion counselling. Although Plan B emergency contraception is now available without a prescription, barriers continue to be faced by those who seek access to it.

Physicians are not required to perform abortions (except in emergency circumstances); however, regardless of their personal beliefs, they should not prevent women from accessing abortion. Health care professionals who withhold a diagnosis, fail to provide appropriate referrals, delay access, misdirect women or provide punitive treatment are committing malpractice and risk lawsuits and disciplinary proceedings. Physicians who prevent women from accessing abortion also breach the CMA's Code of Ethics, which prohibits discrimination on the basis of sex, marital status and medical condition. They also violate CMA policy and positions taken on abortion, including, for example, its positions taken on full and immediate counselling and access without delay.

Physicians must not be complacent concerning access to reproductive health care services for women or the maintenance of rights previously achieved. They should not sit by while abortion services are available only to those who can afford to purchase them. Even if not willing to provide abortion services themselves, physicians should ensure that patients receive the referrals they require, and in a timely fashion. Both the federal and the provincial/territorial governments should be pressed to ensure that publicly funded reproductive health care, including women's constitutionally protected right to abortion, is available and accessible both in clinics and in hospitals. Physicians should work with provincial/ territorial governments and pharmacists to ensure that Canadian women have private, safe and affordable access to Plan B. They should urge the consideration by Health Canada of mifepristone for the purposes of medical abortion.

Canadian physicians should work to ensure that abortion is available to all women who seek it, that the promise of reproductive choice is fulfilled and that initiatives to compromise access are resisted.

\section{Sanda Rodgers \\ Faculty of Law \\ University of Ottawa \\ Ottawa, Ont. \\ Jocelyn Downie \\ Health Law Institute \\ Dalhousie University \\ Halifax, NS}

\section{REFERENCES}

I. Rodgers S. Abortion denied: bearing the limits of law. In: Flood CM, editor. Just medicare: What's in, what's out, how we decide. Toronto: University of Toronto Press; 2006. p. 107.

2. Bowes N, Burstyn V, Knight A. Access granted, too often denied: a special report to celebrate the roth anniversary of the decriminalization of abortion. Ottawa: Canadian Abortion Rights Action League; 1998.

3. Canadian Abortion Rights Action League. Protecting abortion rights in Canada: a special report to celebrate the I5th anniversary of the decriminalization of abortion. Ottawa: The League; 2003. Available: www.caral.ca/PDF/caralreport.pdf (accessed 2006 May 3I).

4. Badgley R, chair. Report of the Committee on the Operation of the Abortion Law. Ottawa: Ministry of Supply and Services Canada; I977. p. I7. 